\title{
The influence of tooth brushing time over saliva buffering capacity
}

\author{
Sri Mulyanti, Hetty Anggrawati \\ Jurusan Keperawatan Gigi Politeknik Kesehatan Kemenkes Bandung
}

ABSTRACT

Saliva gives a considerable influence against the growth of dental caries as a natural defence against caries. the things very important about saliva are it's flow rate and buffering capacity . the decrease in saliva flow rate might cause food retention that furthermore would turn into dental plaques, meanwhile it's buffering capacity will play a considerable role in maintaining the saliva's $\mathrm{pH}$ and reminalization process of the teeth. One of mechanisms which is considered to be effective in preventing dental caries is teeth brushing which could change the $\mathrm{pH}$ of 5,6 to normal level. And the right time of teeth brushing will provide an optimal result. The study aims to reveal the influence of teeth brushing time against saliva buffering capacity. The study is an analytic study using a quasi experimental design. The samples of the study are 20 (twenty) students of dentistry in Health Ministry of Bandung which were purposively selected the sample is divided into 3 groups. The first group is treated by brushing their teeth right after eating bread, the second and third group is treated 15 and 30 minutes after eating bread. The hypothesis uses Kruskall Wallis hypothesis continued by Mann Whitney test, strikethrough. The study reveals that the group brushed their teeth right after eating bread shows low catagory of saliva buffering is that $55 \%$ meanwhile those who brushed their teeth 15 and 30 minutes after eating bread exhibits the result as much as $65 \%$ and $25 \%$ Thus the last group is included to those who have a medium risk of suffering from dental carries. The statistics of Kruskall Wallist test within the confidence level of $95 \%$ shows that there is an influence of teeth brushing time over the saliva buffering capacity with $p<0,001$. Mann Whitney test shows that the time of teeth brushing within 15 minutes after eating is better than the group who brush their teeth 30 minutes after eating

Key Words :teeth brushing time, dental carries, saliva buffering capacity

\section{ABSTRAK}

Saliva sangat berpengaruh pada perkembangan karies gigi yaitu sebagai pertahanan alami terhadap karies. Salah satu faktor penting dari saliva yaitu aliran saliva (saliva flow rate) dan kapasitas bufer. Penurunan aliran saliva akan memicu peningkatan retensi makanan sehingga menjadi plak. Kapasitas bufer saliva merupakan faktor penting, yang memainkan peran dalam pemeliharaan $\mathrm{pH}$ saliva, dan remineralisasi gigi. Salah satu cara mekanis yang dianggap efektif dalam pencegahan karies gigi adalah dengan menyikat gigi. Menyikat gigi dapat mempercepat proses kenaikan pH 5,6 menjadi normal. Untuk mendapatkan hasil yang optimal, penyikatan gigi harus dilakukan pada saat yang tepat. Tujuan 
dari penelitian ini adalah untuk mengetahui pengaruh waktu menyikat gigi terhadap kapasitas bufer saliva. Penelitian ini bersifat analitik dengan rancangan quasi eksperimen. Sampel penelitian adalah mahasiswa Jurusan Keperawatan Gigi Kemenkes Bandung sejumlah 20 orang diambil secara purposive sampling. Penelitian ini dibagi menjadi 3 kelompok waktu menyikat gigi yaitu langsung setelah makan roti tawar, 15 menit dan 30 menit setelah makan roti tawar. Uji hipotesa menggunakan uji Kruskall Wallis dilanjutkan dengan Mann Whitney test, untuk mengetahui kelompok mana yang paling bermakna. Hasil penelitian menunjukkan bahwa nilai kapasitas bufer saliva dengan kategori rendah pada kelompok waktu menyikat gigi langsung setelah makan diperoleh sebanyak 55\%, pada kelompok dengan waktu menyikat gigi 15 menit setelah makan diperoleh sebanyak 65\% sedangkan pada kelompok dengan waktu menyikat gigi 30 menit setelah makan hanya 25\%, sehingga termasuk kedalam golongan yang mempunyai risiko sedang untuk terserang karies gigi. Hasil uji statistik menggunakan Kruskall Wallist test pada derajat kepercayaan 95\% menunjukkan terdapat pengaruh waktu menyikat gigi terhadap kapasitas bufer saliva dengan nilai $p<0,001$. Menurut Mann Whitney test waktu menyikat gigi 15 menit setelah makan lebih baik dibanding kelompok 30 menit setelah makan

Kata kunci: waktu menyikat gigi, karies gigi, kapasitas bufer saliva

\section{INTRODUCTION}

Caries is a destruction process of inorganic components from the hard tissue infected by plaque bacteria. Plaque is a bacteria deposit and its product that attach to the surface of teeth. Firstly, the process of caries is started by demineralization of hard tissue of teeth in which softening processes takes place because of the loss of hydroxyapatite in email, dentin, and cementum. This happens due to the metabolism process of carbohidrate by acid bacteria, of Streptococcus mutans. The occurance will decrease the $\mathrm{pH}$ of the mouth to a critical level $(5,5) .^{1,3-6}$

As widely known, saliva has a big influence over the growth of caries,an a natural defence against it where by it will in volve two important factors of saliva are those saliva flow rate and it's buffering capacity. Saliva flow rate has a significant influence over the grow and development of microorganism colony. The decrease of saliva flow rate will trigger the increase of food retention furthermore become dental plaques, because saliva flow rate has an important role in decreasing the accumulation of dental plaque at surface of the teeth and increase the carbohydrate rate from the mouth cavity. ${ }^{4}$ Buffering capacity is the capacity of the buffering system to overcome the change of $\mathrm{pH}$ resulted by the increase of acid or alkali as a product of Streptococcus mutans which will eventually decrease saliva's $\mathrm{pH}$. The role of saliva buffering capacity is to neutralize the acid of dental plaque and decrease acid potensial hence the process of caries might be obstructed. ${ }^{4}$ It has been proven that Saliva buffering capacity is an important factor that plays a big role in maintaining the $\mathrm{pH}$ of saliva, and teeth remineralization but it basicaly, depends on the concentration of bicarbonate. Bicarbonate concentration may regulate saliva's $\mathrm{pH}$ to get near 6,75 to 7,25 (normal saliva's $\mathrm{pH}$ without stimulation) by determining saliva secretion level. Hydrogen carbonate raises critical pH of 5,6 which may cause email demineralization in dental plaque to reach stimulated saliva $\mathrm{pH}$ of 8,0 On the contrary, carbohydrate diet will evoke saliva's $\mathrm{pH}$ descent which eventually ascend enamel demineralization. The acid production take a time 10 minutes after consuming carbohydrate through glicolic process causing saliva's $\mathrm{pH}$ goes down into critical pH level $(5,5-5,2)$. It takes time quite long is that $30-60$ minute. ${ }^{4}$

The saliva's $\mathrm{pH}$ of 5,6 might be able to increase to get near normal level $(6,75-7,25)$ through teeth brushing that is considered to be effective in preventing teeth caries.

The saliva's $\mathrm{pH}$ of 5,6 might be able to increase to get near normal level $(6,75-7,25)$ through teeth brushing that is considered to be effective in preventing teeth. ${ }^{1,5}$ in order to gain an optimal result, the teeth brushing should be done in the appropriate time. It is not suggested to do right after eating especially after consuming glucose because 5-10 minutes afterward saliva's 
$\mathrm{pH}$ may decrease significantly. The teeth brushing conducted within this moment could worsen teeth erosion due to either mechanical process when brushing the teeth or abbrasive substance contained in tooth paste. The teeth brushing is advisable to do 30 - 60 minutes after eating when saliva's pH has got back to normal level as a result of saliva buffering capacity in neutralizing the acid.

In order to get an optimal result, the teeth brushing should be in the right times. Teeth brushing should not be right after eating, especially after eating with a high amount of glucose. When eating, our mouth is in the attack of acid. It means that the $\mathrm{pH}$ of our mouth decreases; it is indicated by the significant decrease of $\mathrm{pH}$ at least 5-10 minutes after eating.

If teeth brushing is conducted right after eating, the brushing will make the erotion (teeth destruction) worse, both by mechanical process when brushing the teeth and also by abrasive substance contained in tooth paste. If it is continued years after years, the email layer of teeth will get thiner and becone more sensitive. It is better to spend $30-60$ minutes after eating, until the saliva's $\mathrm{pH}$ get back to normal, then teeth brushing can be conducted. Along the time, salive is given a chance to netralise the acid through saliva buffering capacity. 4 Paragraf disatukan dgn di atas: although the teeth brushing is well known as daily activity to maintain oral health, there are many do it within inappropriate time. Thus, the researcher is interested in conducting a study regarding relationship between teeth brushing time and the change of saliva'spH and it's buffering capacity

\section{MATERIAL AND METHODS}

The study uses analysis method with experimental quasi design. The study was conducted in dental clinic in dentistry mayor (JKG) Health ministry of Bandung. The population of the study is all of the dentistry major's students of Health Ministry, Bandung including 129 people and 20 dentistry student who have teeth caries. The technique of sampling is purposive sampling. The data is analyzed by Kruskall Wallis test and continued by Mann Whitney test.

Procedure: a. The first day, the samples ate a piece of bread with the weight of 20 gram and were asked to brush their teeth directly without tooth paste, then the saliva is stimulated to flow faster by chewing paraffin wax within 5 minutes, and buffering capacity was tested after the saliva was gathered. The second day, the same samples were treated as the first day's treatment And they were asked to brush their teeth 15 minutes afterward without tooth paste since then saliva capacity was tested; b. The third day, the same samples were treated as the first day's treatment and were asked to brush their teeth without tooth paste after 30 minutes eating, and the saliva buffering capacity was then tested.

Using a special pipette, take stimulated saliva from the tube and then pour it into buffer test pad to identify its buffering capacity.

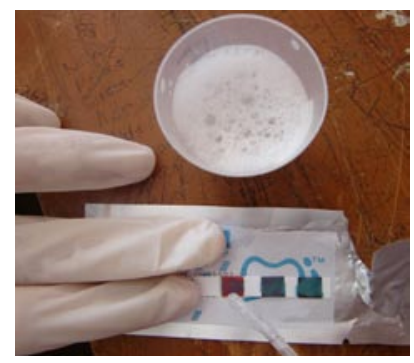

Figure 1. Saliva litmus- type test.

Table 1. Score category of saliva buffering capacity.

\begin{tabular}{cccc}
\hline Score & Buffering Capacity & Colour & Caries Risk \\
\hline $0-5$ & Veri low & Red & High \\
\hline $6-9$ & Low & Yellow & Medium \\
\hline $10-12$ & Normal / high & Green & Low \\
\hline
\end{tabular}

\section{RESULTS}

The influence of teeth brushing time against saliva buffering capacity is describes on the Table 2 below.

Table 2. The influence of teeth brushing time over saliva buffering capacity.

\begin{tabular}{cccc}
\hline Group & \multicolumn{3}{c}{ Score capasitas bufer saliva } \\
\hline Teeth brushing time & $\begin{array}{c}\text { Average } \\
\text { (SD) }\end{array}$ & Median & $\begin{array}{c}\text { Min- } \\
\text { max }\end{array}$ \\
\hline After meal & $7,85(2,11)$ & 8 & $4-12$ \\
15 menit After meal & $6,45(2,18)$ & 7 & $2-9$ \\
30 menit After meal & $5,15(1,38)$ & 5 & $4-9$ \\
\hline${ }^{*}$ Kruskall Wallist test $(p<0,001),{ }^{*}$ Chi Square Test $(p<0,001)$
\end{tabular}


Based on the Table 2, it is clear to see that the lowest score of saliva buffering capacity is in 30 minutes after eating and the result of statistical test using Kruskall Wallist test at the confidence level of $95 \%$ shows that there is a significant influence of teeth brushing time against saliva buffering capacity with the score of $p<0,001$ The influence of teeth brushing time against saliva buffering capacity can be described by this following Figure 2 .

The influence of teeth brushing time against the score category of saliva buffering capacity can be described by this following Table 3 .

As seen on Table 3, there are 11 people (55\%) are included in first category (brushing the teeth right after eating) have saliva buffering capacity low score, 13 people $(65 \%)$ of second category (brushing the teeth 15 minutes after eating) exhibits low score of saliva buffering capacity meanwhile third category (brushing the teeth 30 minutes after eating) demonstrates 5 people (25\%) who have low score of saliva buffering capacity From the Table 3, it can be seen that the statistic result using Chi Square test with the confidence at the level of $95 \%$ shows that there is an influence

Figure 2. The influence of teeth brushing time over saliva buffering capacity.

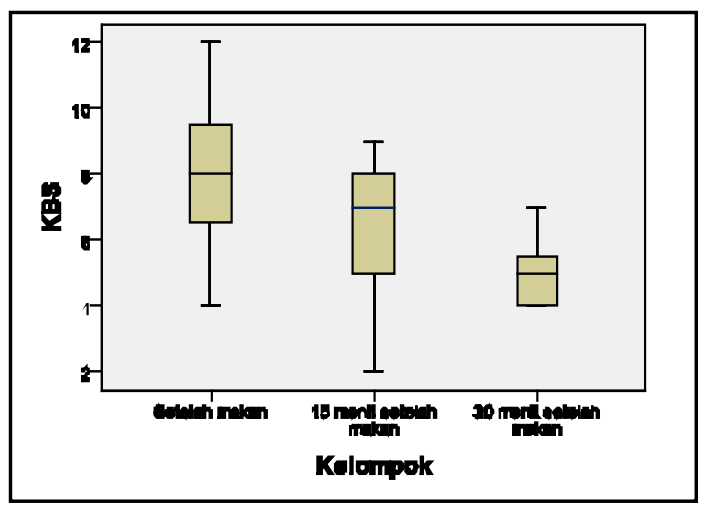

of teeth brushing time against saliva buffering capacity with the score of $p<0,001$.

The influence of teeth brushing time against the score category of saliva buffering capacity can be described in Figure 3, as follows.

The comparison of saliva buffering capacity between teeth brushing time right after eating and 15 minutes after eating can be described by this following Table 4. As seen in Table 4, the result of statistic test using Mann Whitney test with the level of confidence at the level of $95 \%$ shows that there are not any differences of saliva buffering capacity score between the teeth brushing time 15 minutes after eating and teeth brushing time right after eating with the score of $p=0,059$.

The comparison of saliva buffering capacity between teeth brushing time right after eating and 15 minutes after eating can be described by this following Table 5.

As seen in Table 5, the result of statistic test using Mann Whitney test with the confidence at the level of $95 \%$ shows that there is a difference of saliva buffering capacity score between teeth brushing time 30 minutes after eating and teeth brushing time right after eating with the score of $p<0,001$.

Figure 3. The Influence of teeth brushing time over score category of saliva buffering capacity.

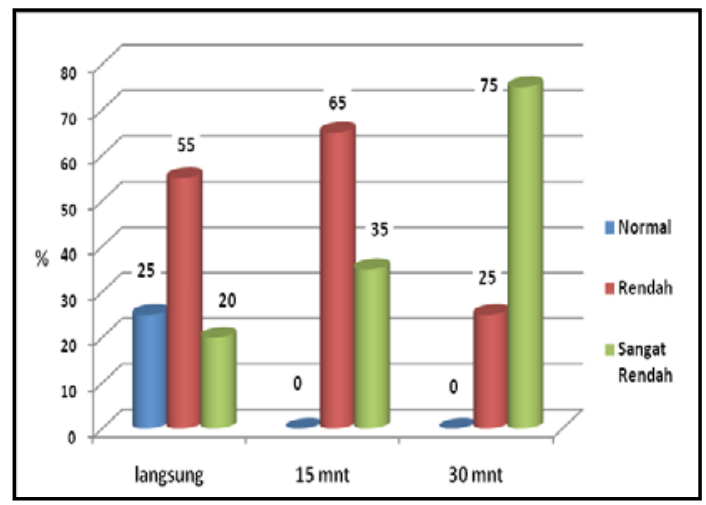

Table 3. The influence of teeth brushing time over the score category of saliva buffering capacity.

\begin{tabular}{ccccccc}
\hline Group & \multicolumn{6}{c}{ Score category capasitas bufer saliva } \\
\hline Teeth brushing time & Normal/high (0-5) & \multicolumn{1}{c}{ Low (6-9) } & \multicolumn{2}{c}{ Very low (10-12) } \\
\hline & $\mathbf{n}$ & $\%$ & $\mathrm{n}$ & $\%$ & $\mathrm{n}$ & $\%$ \\
\hline After meal & 5 & 25,0 & 11 & 55,0 & 4 & 20,0 \\
\hline 15 menit After meal & 0 & 0,0 & 13 & 65,0 & 7 & 35,0 \\
\hline 30 menit After meal & 0 & 0,0 & 5 & 25,0 & 15 & 75,0 \\
\hline
\end{tabular}


The comparison of saliva buffering capacity between teeth brushing time 15 minutes after eating and teeth brushing time 30 minutes after eating can be described by this following Table 6 .

As seen in Table 6, the result of statistic test using Mann Whitney test with the confidence at the level of $95 \%$ shows that there is a difference of saliva buffering capacity score between teeth brushing time 15 minutes after eating and teeth brushing time 30 minutes after eating with the score of $p=0,030$.

Table 4. The comparison of saliva buffering capacity between teeth brushing time right after eating and 15 minutes after eating.

\begin{tabular}{cccc}
\hline Group & \multicolumn{3}{c}{ Score capasitas bufer saliva } \\
\hline Teeth brushing time & Average (SD) & Median & Min-max \\
\hline After meal & $7,85(2,11)$ & 8 & $4-12$ \\
15 menit After meal & $6,45(2,18)$ & 7 & $2-9$ \\
\hline
\end{tabular}

*) Mann Whitney test $(p=0,059)$

Table 5. The comparison of saliva buffering capacity between teeth brushing time right after eating and teeth brushing time 30 minutes after eating.

\begin{tabular}{cccc}
\hline Group & \multicolumn{3}{c}{ Score capasitas bufer saliva } \\
\hline Teeth brushing time & Average (SD) & Median & Min-max \\
\hline After meal & $7,85(2,11)$ & 8 & $4-12$ \\
30 menit After meal & $5,15(1,38)$ & 5 & $4-9$ \\
\hline
\end{tabular}

Table 6. The comparison of saliva buffering capacity between teeth brushing time 15 minutes after eating and teeth brushing time 30 minutes after eating.

\begin{tabular}{cccc}
\hline Group & \multicolumn{3}{c}{ Score capasitas bufer sali } \\
\hline Teeth brushing time & Average (SD) & Median & Min-max \\
\hline 15 menit After meal & $6,45(2,18)$ & 7 & $2-9$ \\
30 menit After meal & $5,15(1,38)$ & 5 & $4-9$ \\
\hline
\end{tabular}

\section{DISCUSSIONS}

The study was not conducted to reveal the score of saliva buffering capacity within three different times; right after eating, 15 minutes after eating, and 30 minutes after eating. The results of the study reveal that from the three categories of time, most of the samples have a low score of saliva buffering capacity. Thus they include to the category with a medium risk of suffering from dental caries.

Based on the hypothesis test with the score of $p=0,047<a$, it means that teeth brushing time can influence the score of saliva buffering capacity. However systemic factors play more roles in determining the score of saliva buffering capacity. According to Amerogen, $\mathrm{pH}$ and saliva buffering capacity are always influenced by the changes of days and nights when saliva secretion reaches the highest point during the day, and decreases during the night, it is about $10 \mathrm{ml} / 8$ hours. It is also under control the parotid glands notwihtstanding the low influence. Besides, $\mathrm{pH}$ and saliva buffering capacity are also influenced by diet, secretion flow stimulation, physical condition, and drugs. The existence of saliva flow in mouth cavity also significantly influences the concentration of saliva components secreted by each gland. Stimulations given to saliva parotid gland can increase a number of ions such as calcium, sodium, chloride, and bicarbonate and $\mathrm{pH}$.

One of essential functions of saliva is its action as a buffer that controls the change $\mathrm{pH}$ in various condition. Saliva's and it's buffering capacity are closely related with the composition of bicarbonate that will increase as the flow of saliva increase. Bicarbonate in saliva can neutralized the acid in foods and acid produced 
by bacteria in mouth. Thus it can help prevent dental carries. The changes of saliva flow also influence the concentration of bicarbonate, urea, ammonium, calcium, phosphate and important ions in reaching balance between reminalization and demineralization. 3,4 According to Amerogen, diet can influence saliva buffering capacity. Carbohydrate diet can decrease saliva buffering capacity by increasing the metabolism of acid production from mouth bacteria; meanwhile, protein and vegeTable diet such as spinach will increase saliva buffering capacity by increasing the production of alkali unsure such as amoniak. 4

According to Cameron, saliva plays an important role in carries process. Saliva decelerates the process of carries by cleaning substrate and provides buffer. Saliva is also an essential factor in tissue reminalisation process. 14 One of saliva's important functions is to maintain the health of mouth cavity by limiting the production of acid produced by bacteria fermentation. This production of acid that will destruct email in which it presents as an initial phase of carries growth. Facts show that the indication of acid involvement role in dental carries, in which saliva with a good quality saliva buffering capacity has a neutralization effect over dental caries process. Demineralization of teeth elements can increase the falling of $\mathrm{pH}$ level, meanwhile, the raise of $\mathrm{pH}$ level can create crystals that deviate and accelerate the formation of tartar on teeth. 4 Thus, the $\mathrm{pH}$ of saliva should be maintained to remain constant, it is at the level $\mathrm{pH}=7$ (constant).

One of effective mechanisms in preventing dental carries is teeth brushing which has function to remove food remains and dental plaque Teeth brushing can accelerate the rise of $\mathrm{pH}$ level at 5,6 to normal level ( $\mathrm{pH} 6,75-7,25)$ hence. It will prevent the process of caries.1,5 The results of the study of Surdacka and Stopa in 2005 reveal that there is an increase of saliva's pH after teeth brushing using a tooth paste with xylitol. According to the study conducted by Koerber, A, James L, Burns, M.S, the acid of teeth plaque will decrease from the level of normal $\mathrm{pH}$ to reach the point of $\mathrm{pH} 5$ during 3-5 minutes after eating carbohydrate and the $\mathrm{pH}$ will get back to normal after 20-30 minutes due to mechanic stimulation. . $^{3,5,11}$

Based on the facts above, it can be summarised that the periods between 3-5 minutes after eating carbohydrate is a risky moment of teeth destruction brushing teeth that is conducted whenever saliva's $\mathrm{pH}$ in the mouth is still in critical level might accelerate the destruction of teeth surface. Thus it is not advised to brush the teeth right after eating becauseat that time the mouth has high level of $\mathrm{pH}$ that make the enamel is easily scrapped. 8 Therefore the right time to brush the teeth is 20-30 minutes after eating because at that time saliva's $\mathrm{pH}$ level and it's buffering capacity are in a normal condition The time before sleeping is advisable time to brush the teeth attributed to saliva production which will decline during the night evoking the absence of natural cleaning.

\section{CONCLUSION}

Of those who brushed their teeth right after eating is $55 \%$ low, the score of saliva buffering capacity whose brushed their teeth 15 minutes after eating is $65 \%$ low. The score of saliva buffering capacity of brushing teeth 30 minutes after eating is $25 \%$ samples that belong to low category. Based on Kruskall Wallis test, it is revealed that there is a significant influence of teeth brushing time over saliva buffering capacity with the score of $p<0,001$.

\section{RECOMMENDATION}

It is recommended to brush your teeth 20 30 minutes after eating. Dentist should do saliva test to detect patients with a high risk of dental carries.

\section{REFERENCES}

1. Samaranayake L. Essential microbiology for dentistry. London: Churchill Livingstone. 2006.

2. Badan Penelitian dan Pengembangan Kesehatan Departemen Kesehatan Republik Indonesia, 2007

3. Fejerskov 0. 2006. Dental caries the disease and it's clinical management. USA: Blackwell Munksgaard. 2006. p. 13,26,41

4. Amerongen AN. , Ludah dan Kelenjar Ludah: Arti Penting bagi Kesehatan Gigi, Gadjah Mada University Press: Yogyakarta. 1991. p. 6-22,37-9.

5. Hiremath SS. Textbook of Preventive and 
Community Dentistry. Elsevier. 2007.

6. Rasinta T. Karies Gigi. Jakarta : Hipocrates. 1992.

7. Angela A. Pencegahan primer pada anak yang berisiko karies tinggi. Dent $\mathrm{J}$ Jul-Sep 2005:38(3):130-4.

8. Koerber A, James L, Burns MS. Toothbrushing Patterns Over Time in At-Risk Metropolitan African-American $5-8^{\text {th }}$ Graders: a Brief Communication", J Public Health Dent, 2005;65(4):240-3.

9. Leous P, Palianskaya L, Leous L." Dental Health Behaviour among 2544-year-old Danes" Scand J Prim Health Care 1986;4:51-7.

10. Kressin NR, Boehmer U, Nunn ME. "Increased
Preventive Practices lead to Greater Tooth Retention". J Dent Res 2003;82:223-7.

11. Kidd EAM, Bechal SJ. 2005. Essential of Dental Caries The Disease and Its management. Third Edition. New York: Oxford University Press. 2005;2,7-8,10,18,60-4,110-2.

12. Roberson TM, Harald $\mathrm{OH}$, Edward JS, et .al. 2006. Sturdevant's Art and Science of Operative Dentistry. $4^{\text {th }}$ ed. Mosby, Inc, 2006. p. 65-131.

13. Harris NO, Garcia-Godoy F. Primary Preventive Dentistry. $5^{\text {th }}$ Ed. Connecticut Appleton \& lange. 237-27,568.

14. Cameron AC, Widmer RP. Pediatric Dentistry. London : Mosby Inc. 1998. p. 55-56 